\title{
ВОВЕД ВО АНТИЧКИТЕ КОНЦЕПТИ ЗА ДЕМОНИТЕ: КРАТКА БЕЛЕШКА ЗА СТАРОЕГИПЕТСКИТЕ ВЕРУВАҢА
}

\section{Кратка содржина}

Целта на овој текст е да даде вовед во концептуализирането на злото во рамките на религиозното веруватье, односно да иे ги доближи на македонската публика основните определби во врска со концептот на инкарнираното зло, преку веруваюата во демоните во Стар Египет. Затоа, накратко се понудени основните терминолошки разлаки во врска со употребата на демон и дајмон во антиката, како и основните концептуални рамки на демонското, хибридното и чудовишното. Направена е основна споредба меѓу природата на демоните од источните циивилизации и на дајмоните од грчката интелектуална култура, и фрлен е поглед кон разликите меѓу античкото и христијанското (и модерното) разбиратье на инкарнираното зло, како и на чудовишноста или „меѓупостоенето" на суитествата со несигурен онтолошки статус и потенцијално заканувачка природа.

Обрнато е внимание на "меѓусуитествата" од веруваюата, кои се движат меѓу различните реалности (Земјата и Подземјето, светот на живите и светот отаде, профаното и светото), и кои не смее да бидат определувани како чисто, или само зли и итетни. Во текстот се разгледани видовите демони од аспект на нивната штетност или корисност, како и од аспект на топографската распореденост (талкачки наспроти фиксни); начините на кои итетните (подвижни) демони расејуваат зарази и ги напаѓаат душите и телата на пациентите, како и важноста на магиско-медицинската заштита од нив; и начините на кои корисните демони-чувари (демоните приврзани за одредени места, на земјата или во Подземјето), учествуваат во одржуватьето на безбедноста на одбраните подрачја кои ги заштитуваат. Обрнато е внимание, значи, и на важноста што обете групи демони ја имаат во разбирането на функциониратето на Подземјето.

Античките верувать во демонското, покрај како заканувачко, опасно и злосторничко, подразбираат и амбивалентност во концептите: итетните демони, расејувачи на болещтини, проблеми и маки, дејствуваат понекогаш по налог на божествата, или служат како казнувачи на огрешените во Подземјето. Корисните демони, пак, имаат клучни онтолоики улоги во одржуватьето на рамнотежата на световите, така што функционираат како чувари на портите кон Подземјето, на влезовите во светите места, на светите подрачја, и на лиминалните сфери. Така, со овој текст е направен обид да се истакне потребата од широкоопфатен пристап во разбирането на концептот на демонското. 
Клучни зборови: демон, дајмон, Стар Египет, чувари, Подземјето

\section{Основни „демонски“ терминодошки определби}

Во теориите за религијата, антропологијата и етнологијата, на здите суштества се реферира со раздични термини, често според, локалната религиозна култура што се истражува. Во таа смисла, она што во широкото значење би било едноставно „демон“, во локалното верување е некакво застрашувачко, насилно и штетно суштество кое си има име, природа и карактеристики. Терминот демон има комплексно значење, со раздични конотации во раздични контексти и временско-просторни рамки. Кај Старите Грци, на пример, дајмон (термин што служи како корен за подоцнежното наше демон) било божествено суштество од каков било вид. Религиозните култури од Месопотамија и Стар Египет изобилуваат со текстуални и иконографски примери од кои станува јасно колку важно и разнообразно било верувањето во демоните (односно разновидните демонски суштества).

Концептуализацијата на инкарнирано, персонифицирано демонско 3ло, на демонски дејствители во светот, е мошне важна за египетското верување во начините на функционирање на космосот - од самото одржување на постоењето, до засебните маки во индивидуалната егзистенција. Односно, може да се оди обратно: токму верувањето во магијата и во моќта на демонското дејствување формира една суштинска нишка меѓу индивидуалното човечко егзистирање и нивото на природата, на космосот, подрачјето на боговите. Поимот на магијата, хека, нема пејоративни конотации во јазикот и идеологијата, инаку карактеристични за западноевропското третирање на концептот. Во староегипетската јазична традиција нема генерички термин за демонското (Kousoulis, 2011, IX-X). Зборовите како демон и демонологија (во нивните варијации во модерните јазици), употребувани во современ контекст, влечат корени од јудео-христијанската културна традиција, и затоа често се сметаат за недобри (зди) аспекти на религиозната или уметничка концептуализација, и како поврзани со лоша (религиозна) практика. Нечесно и депласирано е, меѓутоа, да се наметнува ваквата атмосфера на недоверчивост и неодобрување врз концепти кои постоеле илјадници години претходно. Проблем е и постоењето на таквите демонски суштества: најголем дел од нив немаат јасен онтолошки статус кој едноставно би ги сместил во некаква група на суштества изучувана од „демонологијата“, ниту имаат јасен и непроменлив статус и фиксна одредница во египетскиот систем на верување.

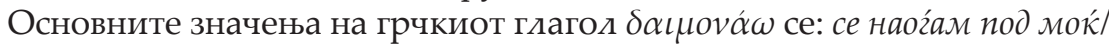
власт на демон, опседнат сум, страдам поради дајмон, и се однесуваат на дејството што (најчесто) зол демон го извршува врз некакво тело или место (Liddell-Scott-Jones online). ${ }^{1}$ Пред Платон нема систематичен третман на

\footnotetext{
${ }^{1}$ За потеклото на терминот според Платон, Евзебиј и други, види кај Riley, 1999,
} 
концептот дајмон, но зборот е посведочен кај Хомер, како широк еквивалент за theos, бог, божествено суштество од каков било вид. Така, значењето се чини неутрално во „со помошта од дајмон“ (Хомер, 1995, А 792), што секако зависи од целта на помошта; или пејоративно, кога Амфимедон обвинува „зол демон“ како причина за враќањето дома на Одисеј (Omero, 2001, 398с5). Афродита е определена како дајмон (Хомер, 1995, 3.420) - во оваа смисла употребата е речиси истозначна со бог/божица. Со терминот во Илијада се означува повремената манифестација на некаква недистинктна натприродна или божествена моќ (преку милоста на божествената моќ, 11.792; спротивставувајќи ѝ се на божествената моќ, 17.98). Дајмон може да се однесува и на моќта што ја контродира судбината, односно (не)среќа што му се случува на човека (Хомер, 1995, 8.66).

Хесиод раскажува како луѓето од златното доба, преку волјата на Sевс добивале посебна функција после смртта и се сметале за чисти духови кои живеат на земјата, кои се добри, избавуваат од штета и општо ги штитат смртниците (Esiodo, 2010, 122-123). Во Дела и дни тие невидливо се движат по земјата, распоредувајќи богатства и забележувајќи го правилното и неправилното однесување. Нивното подрачје на дејствување е, значи, земјата, наспроти тоа на небеските богови, што се протега на недопирдивите сфери отаде овој свет (121 - 126). За нив пишува и дека постојат како „десет илјади духови“ кои внимаваат на сите живи луѓе низ целата земја (252 - 253). Поради нивната издигната позиција (од човечка смртност кон боголика бесмртност), Хесиод го употребува зборот дајмони, кој и кај Хомер инаку се применува на божествата. Во Платоновите дела, во Одбрана Сократова дајмонот е нижо божество (27с-е); во Кратил е замината душа (397е-398с); во Гозба терминот се однесува на посредничките духови (202d-203а); во Држава (620d) и Фајдон (107d), пак, на духовите заштитници. ${ }^{2}$

Онтолошкиот систем на платонистот Апулеј е доста сложен и структуриран во неколку (понекогаш не особено јасни) тријади, од кои една е тријадата на богови, демони и луѓе, а следната поделба е таа на Првиот Бог, невидливи богови и видливи богови. Потоа доаѓаат демоните: бестелесните демони, полутелесните демони и телесните демони. Следна, мошне нејасна тријада, е таа составена од Бог/Идеите, Идејата (Идеите) и материјата. Бог според Апулеј може да биде едвај некако разбран, слично на Доброто од Држава, кое може да биде сфатено иди интуирано. Трансцендентноста на врховниот Бог според Апулеј не претставува проблем, токму затоа што меѓу Бог и подрачјето на смртниците постои посредувачкиот свет на демоните.

Во делото De Deo Socratis Апулеј пишува дека дури и човековата душа во одредена смисла се нарекува демон(ска) додека престојува во телото. Тој се прашува во врска со тоа дали боговите потпалуваат желби во нашите умови, или се работи за желба која во секого се пројавува како не-

235.

${ }^{2}$ Темелно разгледано кај Brenk, 1986, 2068 - 2145, особено 2085 - 2087. 
гов бог (овде можеби посоодветно би било да се употребува дајмон). Добрата желба на душата е добар бог (затоа некои се благословени со добар демон/дајмон и душа совршена по доблест). Душата која се повлекува од служење на земјата (односно бивање во телото) е исто така демон. Апулеј определува и повиш и подостоинствен вид на демони, кој по бројност не е помал од другите, но по достоинство е мошне супериорен, кој е слободен од пречките и ограничувањата на телото, и има одредени моќи. Како примери Апулеј ги наведува Сонот и Љубовта, чии моќи се контрастни едни на други (Љубовта има моќ да пробуди, да подбуцне во дејство, Сонот има моќ да успие, да смири, Apuleius, 2017, 15, 150 - 16, 155). Овој трет вид е сличен на првата схема на демонското подрачје како посредувачко меѓу боговите и иуѓето. ${ }^{3}$

Ако под демон се мисли на индивидуално суштество од чисто духовна, или инкарнирана природа, со кое луѓето може да се сретнат или да имаат некаква интеракција, тогаш нема раздика меѓу египетската концепција за демоните и античката грчка концепција за дајмоните. Сепак, додека постои јасна дефиниција на категоријата на богови, не се наоѓа „аксиоматски термин кој би ги вклучил сите аспекти од, демонската идиосинкразија“ (Kousoulis, 2011, XI). Некои автори ги сметаат демоните како дел од категоријата на боговите, и ги раздикуваат меѓу божествата кои дејствуваат како помошници на богот создател, демоните, и духовите (Meeks, 1971, 18-84; Meeks, 2001, 375-378). Во оваа смисла египетските демони се нижи божества, помошници на повисоки моќи, или „инкарнирани“ дејствители на хаосот и злото (Te Velde, 1975, 981; Meeks, op. cit., 375).

\section{Основни концептуални разграничувања}

Злокобноста со која се поврзуваат демоните низ христијанството никако не може да се припише, или барем не како единствена или доминантна карактеристика, на демоните од Месопотамија и Египет. Ова важи и за слични концепти. На пример, чудовишноста како концепција не е типична за претхристијанските култури, или барем не како нешто што се поврзува со моралните категории. Чудовишните облици се сметаат за манифестација на здото, на непознатото, на здокобното; чудовиштата се често инкарнирано зло (Lucarelli, 2013, 14; Wengrow, 2011, 131-149), но не секогаш се само, чисто, зди. Она што се смета за чудовишно во Стар Египет

\footnotetext{
${ }^{3}$ Концепцијата за третата класа демони, која не постои во инкарнирана форма, е онаа од Гозба, за демонската природа како посредувачка меѓу боговите и дуѓето. Во врска со инспирацијата за човековата душа, лесно се лоцира Тимај, каде рационалниот дел на душата е нешто што Бог го дава како демон на секоја индивидуа (90а). Душата која заминала од земското постоење и станала демон може да се пронајде во Кратил (добар човек кој починува има голема чест и станува демон, 398b-c). За онтолошката схематика кај Апулеј и распоредот на демоните, види кај Тодоровска, 2018, 176-185; 2020, 94-101.
} 
е производ на композитниот стил на претставување, специфичен за културата, што води потекло во пиктографскиот хиероглифичен систем: полиморфијата на суштествата кои дичат како чудовишта и се наоѓаат во списоците на натприродни суштества што го населуваат Подземјето е всушност манифестација на нивните бројни моќи; а нивните форми на пројавување се понекогаш слични или идентични со тие на хибридните богови (кои се чести во Египет).

Во Месопотамија хибридните суштества се главно демонски, и постои изобилство на чудовишта, но и диференцијација меѓу нив и антопоморфните „цивилизирани“ богови. Мешаните суштества или меѓусуштества (од германските кованици Misch/en/wesen и Zwischenwesen) се суштества со мешана природа, кои имаат хибридна физичка форма, односно се духовно посреднички суштества меѓу повисоката и пониската онтолошка сфера. Демонот удуг (односно утуку) може да биде токму иош (хул/лемнуту), но може да биде и амбивалентен и добар; лама се добронамерни суштества кои може да бидат и штетни. Познат е случајот на демонот Пазузу, кој иако е злокобен и штетен (носи ветришта и бури, глад во периодите на суша, наезди на штетници и други неволји), помага во заштитата од други зди вдијанија, штитејќи ги луѓето од зарази и несреќи.

Смит определува „локативна“ категорија на чудовишта, инспириран од моделите на таксономија на Даглас и други автори. Чудовиштата (и бројни демони) живеат во местата надвор од уредениот свет, како пустините, океаните, перифериите на уредената сфера, подземјето (Smith, 1978, 429). Ова е интересна забелешка од аспект на феноменологијата на местото: ако се направи обид чудовиштата да не се раздикуваат од демоните само според нивниот изглед (како хибриди со повеќе композитни животински тела на чудовиштата, наспроти хибриди со човечки карактеристики или атрибути кај демоните), тогаш може да се тврди дека чудовиштата им припаѓаат на местата повеќе од демоните. Демоните „бегаат од местото“, претставувајќи го хаотичното, далечното, неодреденото, бунтовничкото (ibid). Тие се талкачи (неслучајно една од египетските банди на демони се нарекува токму така, „Талкачи“). Покрај ова, меѓутоа, постојат и демони кои се врзани со одредени места, како оние од Подземјето, или чуварите на светите простори.

Телесноста на демоните е еден од проблемите во нивното онтолошко определување. Така, во египетските погребни композиции, демоните имаат тела, и тоа најчесто од хибридна природа, што е исто така типично за демоните од Месопотамија (Black and Green, 1992, 64 - 65). Христијанските концепции за демоните не се токму за „инкарнирано“ зло, затоа што не се работи за телесни, туку повеќе за духовни суштества. Физичката манифестација на демоните може да биде симбол за човековиот конфликт со себе и со моралните начела, симбол на некаква когнитивна дисонанција. Физичките манифестации на демоните во христијанската иконографија инклинираат кон чудовишното, доживеано како абјектно. 
Кај Хомер и во некои од раните грчки фолклорни концепции, се забележуваат сличности со староегипетските верувања за демоните како независни суштества кои припаѓаат на надворешниот свет. Во оваа смисла, можно е Платон да реелаборирал веќе постоечко фолклорно верување, кое веќе се наоѓало кај Хомер, според кое демоните не се дел од внатрешното јас на човека, туку сосема спротивно, тие се персонификација на надворешните натприродни моќи кои предизвикуваат обесчестување иди лудило (што игра централна улога кај Ајсхил, Aeschylus, 1991, 1006 на пример; види кај Wilford, 1965, 217 -232).

Дајмонот (вообичаено индивидуално споменуван, не како дел од колектив) може да дејствува како боговите, но од нив се раздикува по тоа што останува недефинирлив и анонимен. Ваквиот концепт потем се развива во Платоновата идеја за душата што припаѓа на индивидуата, во контраст со антропоморфните богови. ${ }^{4}$ Грчката дајмонологија, значи, се раздикува од, демонологијата на блискоисточните верувања, која се однесува на категоријата на демоните кои се пројавуваат како хибриди, животински или антропоморфни суштества, и кои се често во центарот на апотропејските ритуали за намалување, или менување на нивните влијанија врз животите (и смртта) на луѓето.

Се претпоставува, меѓутоа, дека демонологијата на Блискиот Исток влијаела врз грчката мисла во претставата на потенцијално зди духови во животинска, или доминантно хибридна форма, со телесни компоненти од птици или змии, на пример (може да се спомене појавата на асирискиот грифон-демон, кој често бил прикажуван во пар со сфингата околу 14 век пр. н. е во Грција, Black and Green, 1992, 99 - 101). Буркерт ги разгледува блискоисточните влијанија на грчката демонологија, најчесто фокусирајќи се на справувањето со болестите со демонско потекло, и низ компарација на мотивите и концептите, како Ламашту и Ламија, на пример (Burkert, 1992, pass.). Страшната фигура на Гело, со кого се заплашувале децата, се споменува во делата на Сапфо - за Гело се велело дека краде и јаде мали деца. Уште пострашен лик од Гело е Ламија, веќе спомената во архаичниот период и зачувана низ модерниот фолклор (види кај West, 1991, 361 - 368). Дамија е гротескна, одбивна и одвратна надвор од секаква мера, и главната карактеристика ѝ е што краде деца, понекогаш дури и од утробата на

${ }^{4}$ На фолклорно ниво има сосема малку материјал, смета Бренк (Brenk, 1986, 2040). Она што го имаме од раниот империјален период е комбинација на филозофска книжевност, со често повикување на Платон, и само со парченца народни верувања. Затоа, тешко е да се каже колку точно може да се реконструираат верувањата. Како што беше споменато, дајмоните биле изедначувани со духови на природата, а во филозофската традиција тие се третирале како душата или умот на индивидуалното човечко суштество. Сепак, можно е да се заклучи дека филозофските автори ја третирале демонологијата со извесно колебање, и како подрачје со простор отворен и за верување и за сомничење. Затоа, се чини дека кај филозофските автори е посоодветно да се говори за дајмонологија, која своите корени ги има во фолклорната и Хомерската традиција (ор. cit., 2041). 
мајката. Во оваа смисла мошне наликува на демонот Ламашту. Постои и сличност во имињата, која била замаглена поради раното читање на името на Ламашту како Пабарту (Burkert, 1992, 83).

Околу Медитеранот, фантастичните sверки, како грифонот и сфингата, припаѓаат на иконографијата на демонското, а демонското е често поврзано со чудовишното. Сепак, треба да се има предвид дека она што за нас се чини гротескно, како комбинација на елементи од раздични суштества, екстра глави или екстремитети и слично, разгдедувано во соодветниот контекст е всушност спој на редигиски симбоди, а не опис на здото низ чудовишното и грдото, односно абјектното. ${ }^{5}$ Во рамките на магиските и ритуалните контексти поврзани со култот во храмовите, поииморфиските слики на боговите и на демоните во грчко-римскиот период се бројни (Fischer, 1987, 12-26 apud Lucarelli, 2011, 114, ft. 16/non vidi; Hornung, 2000, 19).

За некои од демоните се верувадо дека се создадени од боговите, за лични цели, други биле човечки суштества (живи или поверојатно мртви). За демоните се верувало дека вршат и услужна функција: тие им помагале на божествата во комуникацијата со луѓето, за да не мора божествата тоа да го прават (Meeks, 2001, 375). Во оваа смисла, демоните се онтолошки и дејствено меѓу божествата и дуѓето. Општо говорејќи, нема култ кон демоните - не до Новото кралство и ако се изземе Сет, кој е сепак бог, а не демон (Te Velde, 1975, 981; Assmann, 2001, 7-8). Иако се говори за „демонска природа“ иди „демонски вдијанија“ треба да се има предвид дека моќите на демоните не биле (сметани за) универзални, туку дека нивниот вид и распон зависат од карактеристиките, улогата и рангот на демонот. ${ }^{6}$

\section{Штетни демони}

Стравот од демони бил широкораспространет низ Стар Египет, а справувањето со нив комбинирало духовни и медицински методи. Магии, пораки и модитви биле придружувани со инстанции од медицинската пракса. Постоеле инкантации и строга ритуалистика за борба против здите напаѓачи.

Се верувало дека анонимните хорди демони; групите, или банди на непријатели и соперници на боговите; неоправданите мртви и проколнатите; сите непријателски настроени преобразени духови; посебните групи

\footnotetext{
${ }^{5}$ Види ги сугестиите кај Bazin, 1992, 25 - 43. База препознава „демонски стил“ во уметноста (слики на митските претстави на врховниот непријател, кои покажуваат грдотија, мноштвеност, претераност, хаос), кој бил популарен во источните цивидизации, и кого го поставува во контраст на грчката уметност, ослободена од дијаболични вдијанија (op. cit., 29).

6 За задачите на демоните, и нивното собирање во банди, види кај Meeks, 1971, 44 - 45; Wilkinson, 2003, 81.
} 
на демони на темнината, носачите на болести, гласниците и кољачите, ${ }^{7}$ кои заедно со боговите го населувале подрачјето после смртта, или подземниот свет (Подземјето), биле способни да ја преминат границата меѓу световите, и да напаѓаат како разбојници, да предизвикуваат физички и ментални болести, емоционална растроеност и разни други проблеми, запоседнувајќи ги животните простори, телата и душите на луѓето. Бројни инкантации се поврзани со заштитата од ваквите зди суштества. Поделбата на демоните во Стар Египет, врз основа на разни магиски изрази, прескрипции и апотропејски средства ${ }^{8}$ може да биде според посебните состојби или болести што ги произведуваат, и соодветните начини за заштита од нив.

Покрај штетните демони кои предизвикуваат неприлики и болештини, постојат и корисни, добронамерни демони, чија улога е да ги штитат местата и луѓето. Демоните се групираат по седуммина, или во парови или тројки, но често е и самотното дејствување, како една посветена (демонска) дичност. Ако се следи поделбата според светот на живеење, тогаш, се делат на две категории. Така, постојат оние кои живеат во подземјето, фиксни, врзани за одредено место кое им служи како дом (Lucarelli, 2013, 17). Втората категорија се состои од демоните кои патуваат меѓу земјата и светот отаде, дејствувајќи низ средината на луѓето по наредби на боговите. Овие се талкачките демони, кои се движат од едно на друго место, и се виновни за ширењето на заразните болести, несреќите и непридиките, и разните видови на демонска запоседнатост. Овие две категории се дистинктни, но може да се претпостави дека на некој начин тие се надоподнуваат во религиозното верување во инкарнираното зло (Lucarelli, 2006, 204).

Талкачките демони се ретко претставувани, но се споменувани со колективни имиња во амајлиските и магиските текстови. Примарните извори на знаењето за демоните кои предизвикувале неволји и штета врз пуѓето се инкантациите и маѓепсувањата зачувани на папируси и острака. Магијата вообичаено се состои од рецитација, и од серија ритуалеми со строго определени состојки кои треба да бидат направени и употребени. Голем број од магиите се замислени како медицински интервенции, за да помогнат со физички и ментални здравствени состојби, или како формули за заштита на индивидуите иди местата од земни или натприродни натрапници.

\footnotetext{
${ }^{7}$ Во магиските текстови имињата на овие три главни демонски банди се употребуваат наизменично, веројатно поради фактот дека сите имаат иста основна функција: да извршуваат казнување, донесувајќи чуми, болести, глад и неволји (Lucarelli, 2017, 58).

${ }^{8}$ Суштествата што се содржат во енциклопедиските текстови, кои Старите Египќани мошне темелно ги уредувале, се оние што биле сметани за жители на космосот. Суштествата на хаосот, како демоните, не се содржат во ваквото набројување. На пример, види во хиерархискиот список на категории на натчовечки суштества од Ономастиконот на Аменимоп (Gardiner, 1947, 37).
} 
Главната улога на демоните „кољачи“, како што се очекува од името, е да донесуваат болести, чуми и болка. ${ }^{9}$ Во оваа смисла, биле сметани и за пратеници на божицата Секхмет, божицата на болештината и стравот (во нејзиниот штетен аспект, Schipper, 2007, 7). Најголем број од магиските текстови од Новото кралство споменуваат магиски практики што се изведуваат за исцелување од физичките и психичките растројства предизвикани од кољачите (Borghouts, 1978, 14-15).

Групата гласници имаат слични зди вдијанија. За нив се сметало дека се пратени да извршуваат укази од боговите, и поради тоа имале и добра и лоша улога, во зависност од тоа во што (за кого иди против кого) требало да интервенираат. Тие се поврзуваат со раздични божества, но во погребните, магиските и храмовските текстови се гласници на Секхмет, или на Сет, што ги прави доминантно деструктивни (Te Velde, 1975, 983; Lucarelli, 2017b, 136). Незаменлива функција на овие божествени гласници е казнувањето на грешниците во подрачјето на мртвите, во последниот суд (на пример: ... ако оваа книга се употребува на Земјата, тој /починатиот/ не ќе биде земен/грабнат од гласниците кои ги напаѓаaт оние што се огрешиле на Земјата“, Книга на мртвите/КM \#163, Lepsius, 1842, pl. 77.17-18, apud Lucarelli, 2005, 205).

За демоните се верувадо дека не гледаат, иди дека имаат урокдиви очи. Попреченоста не завршува тука - се сметало и дека се глуви или дека имаат проблеми со говорот, односно дека говорат неразбирдиво, дека завиваат иди врескаат. Родот на демоните не е пресуден, иако доминантно е споменувањето на машки демони (Te Velde, 1975, 981).

Античките египетски медицинско-магиски работници (лекари, магови, исцелители, свештеници) биле свесни за потребата пациентот да биде ослободен од демонот на болеста, да биде избавен од моќ која доаѓa од светот отаде, од делумно божествени (или речиси божествени), опасни демонски суштества. Затоа, третирањето на епифеномените на болеста, како и на причините за заболувањето, било поефикасно доколку е придружено со магична амајлија, или магиско посакување. Интересно е пра-

\footnotetext{
${ }^{9}$ Поради често повторувачката и востановена демонизација на болестите, заедно со медицинските прескрипции биле употребувани бројни магиски практики и инкантации. Затоа, во Стар Египет станува збор за магиско-медицинско пристапување кон лекувањето и кон јавното здравје (во рана форма). Од многубројните сведоштва од магиско-медицинските папируси, кои биле мошне популарни во Рамзескиот период (со потекло уште во Средното кралство), јасна е примената на ваквата синергија. Од зачуваните извори се знае дека магијата и обредите за отстранување на демонските болести од телото (односно егзорцизмот на демоните) биле сметани за моќни алатки, комплементарни на медицинската наука.

Од достапните извори се чини дека болестите кои не се презентираат со видливи физички симптоми, како главободката и епилепсијата, биле почесто поврзувани со демонското, отколку другите типови на состојби, како отровните каснувања од инсекти. Дерматовенеролошките болести, пак, биле често сметани за манифестации на демонски вдијанија (види Leitz, 1999, 55-57, 80-81; Lucarelli, 2017, 55).
} 
шањето за толкувањето на текстовите каде се споменуваат демоните кои носат болести - можно е да се работи за персонификација на болеста, или за техничка употреба на демонските имиња во медицинскиот жаргон за изразување на идејата за болеста. Доколку тоа е случај, тогаш се работи за разбирање на болеста како екстерен напаѓач или натрапник во телото (разработено кај Pinch, 1994, 133-146). Особено е интересно да се замисли како античките египетски лекари и медицинско-магиски работници би ги разбирале автоимуните заболувања, односно дали би се работело за верување во интерен напаѓач (самото тело на пациентот) разбрано како демонско самонаштетување.

\section{Корисни демони}

Беше споменато дека демоните-гласници се поврзани со Подземјето. Тие служат како извршувачи на божествените укази, а во подрачјето на мртвите соработуваат со Озирис, како негова војска. Тие, значи, имаат двојно влијание, и во овој свет и во Подземјето. ${ }^{10}$ Постоењето на гласниците како демони кои носат болести и неволји, и како помагачи во Подземјето, оди во прилог на замаглените граници на световите во Стар Египет, а со тоа и на погребната и секојдневната магија. Овие демони се споменуваат во погребните текстови и во магиските текстови од Новото кралство и подоцна, кои се однесуваат со секојдневната магија од вообичаениот живот (на живите). Дукарели забележува дека иако е вистинито дека треба да се раздикуваат две реалности кога се говори за демоните во Стар Египет - светот на живите и на мртвите - овие реалности се чинат комплементарни во религиозното верување во здите духови. Демоните од дневната религија и оние кои се споменуваат во амајдиските и магиските текстови понекогаш се истите што се појавуваат во погребните текстови. Идејата за барање божествена интервенција и заштита во одбивањето иди смирувањето на овие демонски сили останува иста и во светот на мртвите и на живите (Lucarelli, 2017, 57).

Талкачките демони кои носат болести се појавуваат и во немедицински контексти, во ритуалните текстови на храмовите, како и во инкантациите на погребната магија. Од една страна, ова значи дека демонизирањето на болестите е тесно поврзано со божествената и ритуалната религиозна сфера, а од друга страна, дека демоните не се само зди или штетни. Потфрлањето во ритуалните должности за смирување на потенцијално гневните богови и десакрализацијата на тајните (диминални) премини може да предизвикаат демонски вдијанија како одмазда.

Интересна е амбивалентната природа на демоните во смисла на тоа дека биле сметани за суштества кои се движат по работ на границите меѓу

${ }^{10}$ Беше спомената \#163 од KM, каде стои формулацијата дека ако книгата се употребува на Земјата, оној кој ја употребува нема да биде грабнат од гласниците кои се непријатели на огрешените. 
божественото и човечкото, кои минуваат меѓу светот на мртвите и светот на живите, кои се на работ на космосот и на хаосот, исполнувајќи ги начелата и на Ма'ат (редот, хармонијата, праведноста, вистината итн.), и на Исфет (хаосот, насилството, неправдата, невистината), така што можеле и да казнуваат за здото дејствување, и самите штетно да дејствуваат, да спасуваат, да штитат и да го одржуваат доброто, а и да предизвикуваат неволји, болести, кошмари, караници и други непријатности.

Добронаклонетите демони во Стар Египет се чуварите на некои од подрачјата на Подземјето и на светите места, кои стануваат зди и штетни кон оние кои не ги знаат соодветните магични зборови, или тајните имиња на демоните, кои се потребни за средба и поздрав со демоните, за да се овозможи безбеден премин. Овие чувари се дел од бројните жители на подземниот живот после смртта, каде богот на сонцето кој се симнува во неговото патување во Подземјето треба да се спои со починатото тело на Озирис. Овие, дури, со резерва може да се сметаат и за „апотропејски богови“" (Altenmueller, 1977, 635-640).

Чуварите и заштитниците на диминалните зони, на влезовите, премините, и, особено на Озирис во процесот на неговото умирање и повторно раѓ⿱⺊е, се мошне важен дел од апотропејската практика. Овие чувари, добронамерни демони, за време на фараонскиот период служеле како набљудувачи и чувари на портите кон Подземјето и кон светите места на Земјата. Карактеристиките и функциите на овие демони биле продолжение на верувањата во нивната природа од митодогијата за светот отаде од претходните периоди. Може да се претпостави дека врската меѓу храмовите, гробниците и демоните-чувари е резултат на развивањето на концептот за смртноста на боговите (или за смртните богови), според кој боговите, како и смртниците, стареат и умираат. Но, постоењето на демоните-чувари и прилично распространетата пракса на чување на светите места од страна на натприродни суштества не се поврзуваат со, ниту одат во прилог на, концептот за смртни богови. Поедноставно и поверојатно е дека демоните-чувари на храмовите, на светиот простор и на Подземјето, се особено важни поради нагласената потреба за чување на храмот-светот, односно космосот, од хаосот на непознатото и заканувачкото. ${ }^{11}$

Чуварите се топографски ограничени, и имаат добронамерна функција кон оние кои имаат тајно знаење за нивните имиња и за тоа како да се соочат со нив во Подземјето, или имаат заштитна функција на одредени свети места, каде нивната моќ е најизразена. Тоа се демоните (чувари), иди wrt-демони од Пророчките амајлиски декрети. Овие доминантно фиксни демони се поврзани со природните места кои ги населуваат, како реки иди планини, и нивното штетно вдијание е врз неовластените минувачи, кои ги

\footnotetext{
${ }^{11}$ Ваквото објаснување одговара со содржината на магиските формули 144-147 од КМ во кои се претставени демонски житеди на Подземјето, кои се чувари на портите. Чуварите на важните елементи на Подземјето се и чувари на светите места во светиот простор на Земјата.
} 
напаѓaат (Leitz, 2002, 506). Ваквата агресивна природа на демоните чувари не е злобна per se - тие се силно заштитнички настроени кон местата за кои се одговорни. Затоа, тие суштински се раздикуваат од талкачките демони кои расејуваат болест, ги освојуваат човековите тела, или прават наезди на места на кои инаку не им припаѓаат. Демоните чувари се клучни во заштитата на светот отаде, затоа што ги чуваат портите и подрачја на светот на мртвите, како и диминалните подрачја за кои се назначени.

Суштествата кои внимаваат на порти, портали и врати се опишани во KM, 144-147; вратите и чуварите на вратите кон Подземјето се тема и на други погребни текстови, како Книгата на портите и Книгата на ноќта. Демонските чувари на светите лиминални места, меѓу Земјата и Подземјето, меѓу живите и мртвите, светото и профаното, чистото и нечистото, се присутни и низ верувањата во Месопотамија, како и во будизмот и хиндуизмот, на пример. Во магиските записи од КM, починатите комуницираат со чуварите на вратите, често во директен дијалог. ${ }^{12}$

На онтолошко рамниште, се работи за демони, не за божества (и секако не за луѓе). Во случајот на чуварите на вратите, нивните моќи и функции се фокусирани на диминалното свето (преодно) место кое го чуваат. Во пиктографските претстави тие се хибридни суштества (човечко тело со животинска глава) или сосема антропоморфни. Тоа што овие демони се и визуелно претставувани, за раздика од другите демони кои се вообичаено само споменувани, оди во контекст на потребата покојните да ги знаат не само по нивното име, што е неопходно (знаењето на името е еден од главните принципи на погребната магија), ${ }^{13}$ туку и да имаат јасна визуелна претстава, за да умеат да ги препознаат (Lucarelli, 2010, 87; Guilhou, 1999).

Овој текст не се занимава со иконографијата на ваквите варијанти, иако анадизата би помогнала да се идентификува еден прототип од кого произдегуваат раздичните папируси, или, доколку се работи за историја на уметноста што се занимава со потеклото, да се идентификува работилницата која иницијално ги произвела, како и подоцнежните трансформации. Од теолошка перспектива, можно е неконзистентноста на претставувањето (секој чувар има раздична форма на глава, на пример) да ја симбодизира нивната способност за манифестација во раздични облици. Чуварите, кои иницијално припаѓаат на светот отаде, во ритуалниот контекст на птолемајската практика помагаат во засилувањето на војската на заштитници на храмовите. ${ }^{14}$

\footnotetext{
${ }_{12}$ Овие магии се појавуваат и на ковчези, во гробници и во храмови (Kákosy, 1982), а претходниците на 144 и 147 се наоѓаат во Текстовите на саркофазите (Barguet, 1967, 190, 203; Lucarelli, 2010, 86).

13 За неопходноста на знаењето на имињата, и познавањето на бас на светите места, види кај Lucarelli, 2006, 95-104.

${ }^{14}$ Ваквата функција на чувари на Подземјето е можеби инспирирана од постоењето на човечки, смртни чувари на портите на храмовите, што било одговорна и света функција (Leprohon, 1994). Можно е да се работи за инспирираност, секако, но
} 
Функцијата на демоните чувари е да ги отвораат портите кон Подземјето за Озирис, што значи дека имаат клучна космолошко-ритуална димензија во одржувањето на редот преку повторното раѓање и владеењето на Озирис со подрачјето на мртвите. Во верзијата од храмот од Дендера, сцената го покажува Хор, придружуван од Анубис, која го поздравува Озирис на влезот на портите (функција која во папирусите ја исполнувал починатиот, кој има, очекувано, централна улога во контекстот). Во КМ, делови 145 и 146, од папирус од Дваесет и првата династија, починатиот е претставен како им го нуди своето срце на чуварите (види кај GozdawaGolebiowska, 2009). Демоните-чувари се дел од духовите-чувари на храмовите затоа што нивната функција е отворањето на патот, односно на преминот, на вратите и портите што ги оддедуваат раздичните подрачја (светото и профаното, земското и подземното). И погребната магија (отворањето на портите на Подземјето) и ритуадите во храмовите (пристапот кон најскриените простори каде се изведуваат тајните ритуалеми) зависат од ваквата способност. Затоа, демоните-чувари се суштински дел од, односно врска меѓу, секојдневната ритуална магија, и свечената погребна магија. ${ }^{15}$

Во овој текст е направен прелиминарен обид за доближување кон македонската публика на верувањето во демоните како дел од широкиот и разновиден концепт на инкарнираното зло. Многубројните и повеќеслојни концепции за демоните во Стар Египет служат како соодветен вовед во древните верувања во демонското, натприродното и чудовишното. Иако демоните општо се поврзуваат со, односно вбројуваат во, категоријата на чисто (инкарнирано) зло, во претхристијанските верувања постои амбивалентност на концептот. Демоните (и чудовиштата, односно хибридите) не се само зди и штетни.

во примордијалните верувања движењето на важноста на дејствата е од светото кон профаното - примарно е светото, а поради него, и налик на него, се формира профаното. Затоа, поверојатната претпоставка е дека се работи за комбинирана практично-религиозна функција: на храмовите им треба чување, но тоа е според устроеноста на Подземјето и порталите кон него.

${ }^{15}$ Изјава која се повторува од страна на починатиот $(K H, 145)$ е „отвори ми пат, затоа што те знам, го знам твоето име, го знам името на богот кој те чува“; cf. 144 „вратите на подземјето се отворени за тебе (Озирис)“. Во ритуалот од мистериите на Озирис, во кој треба на Озирис да му се дозводи да владее во име на Тивката земја (Подземјето), се споменуваат раздични демонски и божествени житеди на подземниот свет, од кои се бара на богот (односно на починатиот) да му дадат пристап, да го штитат и да го обожуваат. Во ритуалот е јасно дека клучно е познавањето на имињата на демоните за да се добие дозвола за премин (од Р. MMA 35.9.21, apud Goyon 1999, 17-26).

Темелна споредба на имињата на чуварите од КM, 144 (P. Turin 1791, Lepsius 1842, pls. LX-LXI; од храмот на Дендера, Dendara X, 345-346; Cauville, 1997, 1:186-87, и во ритуалниот папирус на Имотеп, Goyon, 1999, 34-5, cols. 7/16-8/5, pls. VI-VIIA, од Lucarelli, 2010, 93, table 1). 
Затоа, во овој текст е накратко посочена старогрчката концепција за дајмоните, во обид за споредба со египетските верувања. Демоните од Стар Египет се разгледани во нивната двојна функција: на носачи на болести, несреќи, запоседнатост и маки, и на чувари на одбрани, свети места. Амбивалентноста на демонското се забележува и во фактот што дури и страшните и ужасни гдасници-демони, одговорни за мизеријата во светот на живите, всушност исполнуваат укази на боговите, и помагаат казните во светот на мртвите да бидат соодветно извршувани. Демоните-чувари, пак, имаат клучни свети онтолошки улоги во одржувањето на граничните подрачја меѓу слоевите на светот. Затоа, може да се заклучи дека иако демоните не може да се одвојат од концептот на здото (инкарнирано), сепак треба да се разгледуваат и како амбивалентно, а не само како здо и штетно нечовечко (иди натчовечко) постоење во светот. 


\section{ПИТЕРАТУРА:}

Aeschylus, Helen H. Bacon (1991). Seven Against Thebes (Greek Tragedy in New Translations). Oxford: Oxford University Press.

Altenmueller, H. (1977). Gotter, apotropaeische. In W. Helk, W. Westendorf, eds., Lexikon der Aegyptologie, II, Wiesbaden: O. Harrassowitz, pp. 635-640.

Apuleius (2017). Apologia. Florida. De Deo Socratis, C. P. Jones, trans. \& ed. Loeb Classical Library 534, Cambridge: Harvard University Press.

Assmann, J. (2001). The Search for the God in Ancient Egypt, Ithaca and London: Cornell University Press.

Barguet, P. (1967) Le livre des morts des anciens égyptiens. Littératures anciennes du Proche Orient 1. Paris: Les Editions du Cerf.

Bazin, G. (1992). The Devil in Art. In B. P. Levack, ed., Witchcraft and Demonology in Art and Literature, Vol. 12, London: Routledge, pp. 25-43.

Black, J. and Green, A. (1992). Gods, Demons and Symbols of Ancient Mesopotamia. An Illustrated Dictionary. London: British Museum Press.

Borghouts, J. (1978). Ancient Egyptian Magical Texts. Nisaba 9, Leiden: Brill.

Brenk, F. (1986). In the Light of the Moon: Demonology in the Early Imperial Period. ANRW, II, 16. 3, pp. 2068-2145.

Burkert, W. (1992). The Orientalizing Revolution. Cambridge: Cambridge University Press.

Esiodo (2010). Opere e giorni, A. Ercolani (a cura di). Roma: Carocci.

Gardiner, A. H. (1947). Ancient Egyptian Onomastica. London: Oxford University Press.

Goyon, J.-C. (1999). Le papyrus d'Imouthès Fils de Psintaês. New York: MMA.

Gozdawa-Golebiowska, K. (2009). Chapter 146 of the Book of the Dead of wsrHAtms SR 6/10249 TR 14.7.35.7. Cairo: Egyptian Museum Collection), GM 223, pp. 53-56.

Guilhou, N. (1999). Génies funéraires, croque-mitaines ou anges gardiens? Étude sur les fouets, balais, palmes et épis en guise de couteaux. In S. Aufrère, ed., Encyclopédie religieuse de l'univers vegetal, vol. 1, pp. 365-417. Montpellier: Université Paul-Valéry.

Хомер (1995). Илијада, М. Д. Петрушевски, прев. Скопје: Детска радост.

Hornung, E. (2000). Komposite Gottheiten in der ägyptischen Ikonographie. In Images as media. Sources for the cultural history of the Near East and the Eastern Mediterranean (1st millenniumBCE), Orbis Biblicus et Orientalis (OBO) 175, pp. 1-20.

Kákosy, L. (1982). Temples and funerary beliefs in the Graeco-Roman epoch. In L'égyptologie en 1979: Axes prioritaires de recherches. Paris: Editions du Centre national de la recherche scientifique, pp. 117-127.

Kousoulis, P. (2011). Introduction: The Demonic Lore of Ancient Egypt:Questions on Definition. In: P. Kousoulis, ed., Ancient Egyptian Demonology: Studies on the Boundaries between the Demonic and the Divine in Egyptian Magic. Leuven - Paris - Walpole: Uitgeverij Peeters en Departement Oosterse Studies, pp. I-XXI. 
Leitz, C. (1999). Magical and Medical Papyri of the New Kingdom, (Hieratic Papyri in the British Museum) 7. London: British Museum Press.

Leitz, C. (2002). Lexikon der ägyptischen Götter und Götterbezeichnungen, Vol. 2. Dudley, MA, and Leuven: Peeters.

Leprohon, R. J. (1994). Gatekeepers of this and the other world. JSSEA 24, pp. 77-91.

Lucarelli, R. (2017a). Illness as Divine Punishment. The nature and function of the disease-carrier demons in the ancient Egyptian magical texts. In S. Bhayro and C. Rider, eds., Demons and Illness from Antiquity to the EarlyModern Period. Leiden-Boston: Brill.

Lucarelli, R. (2017b). The Significance of the Book of the Dead Vignettes. In F. Scalf, ed., Book Of The Dead, Becoming God in Ancient Egypt, Chicago: Oriental Institute Museum Publications.

Lucarelli, R. (2006). Demons in the Book of the Dead. In B. Backes, I. Munro, S. Stöhr, eds., Totenbuch-Forschungen: Gesammelte Beiträge des 2. Internationalen Totenbuch-Symposiums, Bonn, 25. bis 29. September 2005, Leiden: Brill, pp. 203-212.

Lucarelli, R. (2010). The guardian-demons of the Book of the Dead. British Museum Studies in Ancient Egypt and Sudan 15, pp. 85-102.

Lucarelli, R. (2013). Towards a Comparative Approach to Demonology in Antiquity: The Case of Ancient Egypt and Mesopotamia. Archiv für Religionsgeschichte, Band 14, Heft 1, pp. 11-25.

Lucarelli, R. (2013). Towards a Comparative Approach to Demonology in Antiquity: The Case of Ancient Egypt and Mesopotamia. Archiv für Religionsgeschichte 14, 17, pp. 11-25.

Meeks, D. (1971). Génies, anges et démons : Egypt - Babylone - Israël - Islam - Peuples altaïques - Inde - Birmanie - Asie du Sud-Est - Tibet - Chine. Paris: Éditions du Seuil.

Meeks, D. (2001), Demon. In D. Redford, ed., Oxford Encyclopedia of Ancient Egypt, vol. I. Oxford: Oxford University Press, pp. 375-378.

Omero (2001). Odissea, F. Ferrari (a cura di). Torino: Unionie TipograficoEditrice Torinese.

Pinch, G. (1994). Ancient Egyptian Magic. London: BMP.

Plato (1997). Complete Works. M. J. Cooper, trans. \& ed. Indianapolis: Hackett Publishing Company.

Riley, G. J. (1999). Demon. In: K. van der Toorn, B. Becking, P. W. van der Horst, eds., Dictionary of Deities and Demons in the Bible. Brill: Leiden-BostonKöln, p. 235-240.

Schipper, B. (2007). Angels or Demons? Divine Messengers in Ancient Egypt. In F. Reiterer, T. Nicklas, K. Schopflin, eds., Angels: The Concept of Celestial Beings: Origins, Development and Reception. New York: Walter de Gruyter.

Smith, J. Z. (1978). Towards Interpreting Demonic Powers in Hellenistic and Roman Antiquity. ANRW, 2. 16. 1, pp. 425-439. 
Te Velde, H. (1975). Dämonen. In: W. Helck, W. Westendorf, eds., Lexikon der Ägyptologie, vol. I. Wiesbaden: O. Harrassowitz, pp. 980-984.

Тодоровска, М. (2018). Одредени аспекти од онтолошките системи на Апуиеј и на Нумениј. Филозофска трибина, 41, 22-23, стр. 175-195.

Тодоровска, М. (2020). Неискажливата природа на божественото. Скопје: Фииозофски факултет.

The Online Liddell-Scott-Jones Greek-English Lexicon. Available at http://stephanus. tlg.uci.edu/lsj/\#eid=1 [accessed 01 May 2021].

Wengrow, D. (2011). Cognition, Materiality and Monsters: The Cultural Transmission of Counterintuitive Forms in Bronze Age Societies. Journal of Material Culture, 16:2, pp. 131-149.

West, D. R. (1991). Gello and Lamia, Two Hellenic Daemons of Semitic Origin. Ugarit-Forschungen, 23, pp. 361-368.

Wilford, F.A. (1965). Daimon in Homer. Numen 12:3, pp. 217-232.

Wilkinson, R. H. (2003). Demons. In The Complete Gods and Goddesses of Ancient Egypt. London: Thames and Hudson: p. 81. 
